\title{
PROBLEM KEPEMIMPINAN PENDIDIKAN MADRASAH IBTIDAIYAH DALAM PENGEMBANGAN MUTU SUMBER DAYA MANUSIA
}

\author{
Rahmawati \\ Prodi Pendidikan Guru Madrasah Ibtidaiyah \\ Pascasarjana Universitas Islam Negeri Sunan Kalijaga \\ Jl. Marsda Adisucipto Yogyakarta, Indonesia \\ E-mail:rahmazahra2705@gmail.com \\ Website: https://jurnal.uin-antasari.ac.id/index.php/adzka \\ Received: Juni 2019; Accepted: Juni 2019; Published: Juni 2019
}

\begin{abstract}
This study examines the problem of MI education leadership in the development of $21 \mathrm{st}$ century human resource quality. This study seeks to formulate the problems of educational leadership while formulating solutions to overcome these problems. This study uses a qualitative descriptive approach with data research methods using the process of observation and dokument review. After that, data reduction, data presentation and conclusion are made or verification using triangulation. Good leadership must be able to increase creativity and encourage increased competence and analyze policies that must be updated to face the era of globalization in the 21 st century. The problems of education in Indonesia is: 1) building national character education, which begins with forms of habituation, understanding, leadership and can be applied continuously, 2) basic education for all that guarantees that all children of the nation have the right to education, 3) decentralization and education autonomy must be clear in the distribution of the educational functions between levels of government and measurable as well as written policies or programs financed by the provincial or district goverments.
\end{abstract}

Keywords: problems; leadership; development; quality of human resources; madrasah.

\begin{abstract}
ABSTRAK
Penelitian ini mengkaji tentang problem kepemimpinan pendidikan MI dalam pengembangan mutu SDM Abad 21. Penelitian ini berusaha untuk merumuskan problematika kepemimpinan pendidikan sekaligus merumuskan pemikiran solutif untuk mengatasi problematika tersebut. Penelitian ini menggunakan pendekatan deskriptif kualitatif dengan metode penelitian data menggunakan proses analisis observasi dan kajian dokumen. Setelah itu dilakukan reduksi data, penyajian data dan pengambilan kesimpulan atau verifikasi menggunakan triangulasi. Kepemimpinan yang baik harus dapat meningkatkan kreativitas serta mendorong peningkatan kompetensi serta menganalisis kebijakan yang harus di perbaharui untuk menghadapi era globalisasi pada abad 21. Problem pendidikan yang ada yaitu: 1) Membangun pendidikan karakter bangsa, yang dimulai dengan bentuk pembiasaan, pemahaman, keteladanaan dan dapat teraplikasi secara terus menerus, 2) Pendidikan dasar untuk semua yang menjamin bahwa seluruh anak bangsa berhak mendapatkan pendidikan, 3) Desentralisasi dan Otonomi Pendidikan harus jelas pembagian urusan pendidikan antar tingkat pemerintahan dan terukur juga tertulis berbagai kebijakan atau program yang dibiayai oleh pemerintah, provinsi atau kabupaten.
\end{abstract}

Kata Kunci: problematika; kepemimpinan; pengembangan; mutu SDM; madrasah. 


\section{PENDAHULUAN}

Manusia adalah kekuatan utama dalam seluruh bidang pembangunan bangsa secara nasional oleh karena itu pembangunan pendidikan harus terpadu dan berjalan secara bersamaan, seirama, selaras dan serasi dengan pembangunan pada bidang lainnya. Pendidikan berfungsi sebagai katalisator dalam peningkatan kualitas bagi pembangunan nasional di berbagai bidang, sebagai bagian integral dari sistem perekonomian nasional, pendidikan dituntut menghasilkan pendidik yang cakap, kreatif dan profesional serta produktif juga efisien. Pendidikan dasar bagi generasi muda merupakan tahapan penting untuk menanamkan nilai-nilai kehidupan. Pendidikan dasar menjadi peletak dasar utama mengenai cara berpikir, bersikap serta berperilaku dalam menjalani kehidupan.

Pendidikan sebagai bagian dari usaha untuk meningkatkan tarif kesejahteraan kehidupan manusia, pendidikan merupakan bagian dari pembangunan nasional untuk menghadapi perubahan dalam era reformasi serta proses globalisasi. Pendidikan dasar bertujuan untuk membentuk karakter, kemampuan dan kecakapan dasar yang berguna bagi kehidupan semua warga negara. Salah satu kebijakan pemerintah adalah adanya kebijakan wajib belajar 9 tahun (education for all). Layanan pendidikan dasar dilakukan atas dasar prinsip keadilan tanpa membedakan suku bangsa, golongan, jenis kelamin, tempat tinggal, dan latar belakang sosial ekonomi peserta didik yaitu sebagai wujud pendidikan multikultural (Depdiknas, 2006).

Untuk meningkatkan mutu dan relevansi pendidikan dasar dan menengah maka pemerintah telah mengeluarkan kebijakan dengan menetapkan delapan standar pendidikan nasional yaitu bermuara pada Standar Kemampuan Lulusan (SKL) disetiap jenjang pendidikan. SKL yang meliputi standar isi, standar kompetensi lulusan, standar proses pendidikan, standar sarana dan prasarana, standar pengelolaan, standar pembiayaan pendidikan, standar penilaian pendidikan, standar pendidik dan tenaga kependidikan. Jika SKL disusun dan dilaksanakan secara konsisten diharapkan melahirkan lulusan yang sangat bermutu dan relevan dengan kebutuhan lulusan, masyarakat dan dunia kerja Indonesia. Namun, jika SKL tidak disusun dengan benar dan tidak dilaksanakan sebagaimana mestinya, maka pendidikan tidak akan pernah relevan karena lulusannya tidak akan sesuai dengan berbagai kebutuhan sebagai wujud pendidikan yang berkualitas (Tim PGRI, 2014:69-70).

Sampai sekarang kritik terhadap pendidikan muncul antara lain karena orientasi dan kesadaran yang lemah terhadap pengembangan nilai hakiki kemanusiaan. Pendidikan telah menimbulkan akibat yang sangat serius terhadap pendidikan karakter yang dilakukan dengan mengajarkan tentang nilai. Nilai dapat dipelajari oleh peserta didik tetapi tidak dapat diajarkan. Pendidikan nilai akan berhasil jika dilakukan dalam bentuk pembiasaan, pemahaman, aplikasi dan keteladanan yang berlangsung secara terus menerus, hingga akhirnya peserta didik memperoleh suatu makna dari suatu nilai karakter yang dipelajarinya (Tim PGRI, 2014:75).

Problematika kepemimpinan adalah sebuah masalah kepemimpinan pendidikan yang saat ini menunjukkan kompleksitasnya, baik dari segi komponen, manajemen pendidikan maupun lingkungan yang mempengaruhi keberlangsungan suatu pendidikan tersebut. Kepemimpinan adalah kemampuan untuk mempengaruhi sekelompok anggota agar bekerja mencapai sasaran dan tujuan yang sama (Andang, 2014: 38).

Pemimpin abad 21 harus memiliki jiwa enterprener yaitu harus kompeten, percaya terhadap diri, inovatif punya kemampuan keras, memiliki dorongan untuk mencapai sesuatu. Corporatif ia sangat dominan tetapi tidak suka mendominasi, memberikan kebebasan pada bawahannya dan konsultatif. Devaloper menjadi seorang pembangun yaitu mengganggap orang lain sumber kekuatan, membantu mengaktualisasikan potensi yang dimiliki bawahannya. Integrator ia adalah seorang yang selalu ingin membangun konsensus dan komitmen yang cerdas. 
Kepemimpinan kepala sekolah yang baik harus dapat meningkatkan kreativitas sekaligus dapat mendorong terhadap peningkatan kompetensi pendidik. Sumber daya manusia pendidikan diantaranya terdiri dari: tenaga pendidik, tenaga fungsional kependidikan, tenaga teknis kependidikan, tenaga pengelola satuan pendidikan dan tenaga lain yang mengurusi masalah-masalah manajerial atau administratif kependidikan. Sedangkan Mulyati yang mengutip pendapat dari Mondy, Noe dan Premeaux menyatakan bahwa pengembangan SDM meliputi 4 hal yaitu: 1) pelatihan, 2) pengembangan, 3) pengembangan karir, 4) penilaian kinerja (Mulyati, 2012:46).

Dalam rangka peningkatan mutu pendidikan di madrasah diperlukan sebuah sistem yang bermutu dan berkualitas. Sistem pendidikan di madrasah terdiri dari komponenkomponen yang saling keterkaitan satu dengan yang lain dan saling berhubungan untuk mencapai tujuan suatu madrasah. Semua komponen yaitu guru, peserta didik, sarana/alat pendidikan, tujuan, lingkungan, kepala madrasah, dana, lingkungan dan lainnya sangat penting dalam menentukan keberhasilan pencapaian tujuan pendidikan suatu madrasah itu.(Ibrahim Bafadal,2004:36-37).

Berdasarkan penjelasan diatas pembangunan sistem pendidikan nasional ditantang untuk terus melakukan berbagai langkah inovatif mulai dari tingkatan kebijakan, perencanaan, pengembangan program pembangunan, makro dan mikro, sampai pada penyelenggaraan dan pelayanan pada satuan pendidikan. Berbagai langkah inovatif perlu dilakukan agar pendidikan mampu menjawab berbagai persoalan terutama untuk meningkatkan daya saing bangsa. Salah satu langkah penting dalam melakukan langkah-langkah inovatif itu adalah eksplorasi berbagai problematika kebijakan pendidikan di Indonesia. Oleh karena itu penulis merasa tertarik untuk menelaah problem kepemimpinan pendidikan MI dalam pengembangan mutu SDM di abad 21 serta pemikiran yang solutif.

\section{METODE PENELITIAN}

Penelitian ini menggunakan pendekatan deskriptif kualitatif. Hal ini dengan mendeskripsikan problematika kepemimpinan pendidikan MI yang dikaji dari berbagai sumber. Metode pengumpulan data dalam penelitian ini adalah observasi dan dokumen. Proses analisis data diawali dengan observasi situasi alami dalam kepemimpinan pendidikan lalu kajian dokumen yang digunakan peneliti adalah untuk menggali pemikiran para ahli pendidikan melalui buku dan naskah-naskah yang telah terpublikasi. Setelah itu dilakukan reduksi data, penyajian data dan pengambilan kesimpulan atau verifikasi menggunakan pemeriksaan keabsahan melalui triangulasi dalam menelaah problem kepemimpinan pendidikan MI dalam pengembangan mutu SDM pada abad 21.

\section{HASIL PENELITIAN DAN PEMBAHASAN}

Pengembangan pendidik-pendidik merupakan sebuah keniscayaan dalam meningkatkan mutu pembelajaran di SD/MI. Kecakapan guru SD/MI dalam mengelola pembelajaran mempengaruhi semangat, minat, serta daya tangkap yang dimiliki peserta didik. Semakin pendidik tersebut mampu memberikan pelayanan prima dalam pembelajaran, peserta didik pun semakin antusias untuk paham dan menyerap pelajaran. Hasilnya output yang dihasilkan akan lebih maksimal dan bermutu, oleh sebab itu diperlukan pengembangan guru di SD/MI yang lebih terarah dan berjalan efektif.

Pengelola atau pimpinan SD/MI setidaknya: pertama, menyusun pro pengembangan pendidik dengan memperhatikan kualitas dari standar pendidik dan tenaga kependidikan. Kedua, mengembangkan sesuai dengan kondisi instansi yang terkait termasuk dalam pembagian tugas, menentukan sistem penghargaan, mengatasi bila ada kekurangan tenaga kerja, pengembangan profesi bagi setiap pendidik dan tenaga kependidikan serta 
menerapkannya secara profesional, adil, terbuka dan transparan (Permendiknas Nomor 19 tahun 2007).

Tabel 1. Taksonomi Perilaku Kepemimpinan yang Efektif (Didin Kurniadin \& Imam Machali, 2014:301-303)

\begin{tabular}{|c|c|c|}
\hline Perilaku Khusus & $\begin{array}{l}\text { Orientasi } \\
\text { Umum }\end{array}$ & Pedoman bagi penggunaan efektif \\
\hline Merencanakan/mengorganisasi & Tugas & $\begin{array}{l}\text { Mengidentfikasi langkah tindakan, memperkirakan } \\
\text { waktu/biaya per langkah, memonitor kemajuan, } \\
\text { berkoordinasi. }\end{array}$ \\
\hline Pemecahan masalah & Tugas & $\begin{array}{l}\text { Mengambil tanggung jawab untuk menangani } \\
\text { masalah, membuat diagnosis sistematis, dan menguji } \\
\text { pilihan-pilihan inovatif. }\end{array}$ \\
\hline Memperjelas peran & Tugas & $\begin{array}{l}\text { Mendefinisikan pekerjaan/ prioritas menentukan } \\
\text { tujuan spesifik, yang menantang, menerangkan suatu } \\
\text { tugas yang jelas dan alasannya. }\end{array}$ \\
\hline Menginformasi & Tugas & $\begin{array}{l}\text { Beri akses langsung ke informasi: beritahu orang } \\
\text { tentang keputusan namun jangan berlebihan. }\end{array}$ \\
\hline Memonitor & Tugas & $\begin{array}{l}\text { Identifikasi/ukur/monitor indikator hasil, awasi } \\
\text { operasi, dorong laporan kesalahan. }\end{array}$ \\
\hline Berkonsultasi & Hubungan & $\begin{array}{l}\text { Nyatakan tujuan, minta saran tentang memperbaiki } \\
\text { pekerjaan dan pakailah saran-saran dan komentar } \\
\text { orang lain secara sungguh-sungguh. }\end{array}$ \\
\hline Mendukung & Hubungan & $\begin{array}{c}\text { Berlaku sopan, sabar dan penolong katakan hal-hal } \\
\text { untuk meningkatkan kepercayaaan diri dan harga } \\
\text { diri. }\end{array}$ \\
\hline $\begin{array}{l}\text { Mengembangkan dan } \\
\text { mentoring }\end{array}$ & Hubungan & $\begin{array}{l}\text { Identifikasi kekurangan keahlian, sediakan pilihan, } \\
\text { pengembangan bertindak sebagai suri teladan, } \\
\text { tetapkan contoh perilaku yang bagus. }\end{array}$ \\
\hline Menangani konflik & Hubungan & $\begin{array}{l}\text { Jelajahi persepsi bertindak tidak secara parsial, tahan } \\
\text { perilaku negatif atau merusak. }\end{array}$ \\
\hline Mengenali & Hubungan & $\begin{array}{c}\text { Kenali perbaikan dan upaya yang gagal jangan kenali } \\
\text { hanya puncaknya dan orang-orang yang paling } \\
\text { kelihatan }\end{array}$ \\
\hline Menghargai & Hubungan & $\begin{array}{l}\text { Gunakan penghargaan yang orang anggap menarik, } \\
\text { definisikan kinerja, hargai semua elemen yang ada. }\end{array}$ \\
\hline
\end{tabular}

Abad 21 ditandai sebagai abad keterbukaan atau abad globalisasi, artinya kehidupan manusia pada abad 21 mengalami perubahan yang fundamental. Dikatakan abad 21 adalah abad yang meminta kualitas dalam segala usaha dan hasil kerja manusia yang bermutu, dengan sendirinya abad 21 meminta sumber daya manusia yang berkualitas dan bermutu, yang dihasilkan oleh lemba instansi yang dikelola secara profesional sehingga membuahkan hasil unggulan dan berkualitas. Tuntutan-tuntutan tersebut meminta berbagai terobosan dalam berfikir, penyusunan konsep serta tindakan-tindakan untuk memperbaharui. Kompetensi pembelajaran pada abad 21 adalah keterampilan menguasai media IT yaitu informasi dan teknologi. Keterampilan ini menghendaki peserta didik juga pendidik masa sekarang terlebih masa yang akan datang melek informasi, melek media, dan melek TIK (Etiska Ayu Wijaya, Dwi Agus Sudjimat dan Amat Nyoto, 2016: 263).

Keterampilan seorang pemimpin pada abad 21 meliputi 3R, $3 \mathrm{R}$ itu adalah (1) life and career skills, (2) learning and innovation skills dan (3) information media and technology skills. Inilah pengembangan pendidikan abad 21. (1) life and career skills atau keterampilan hidup dan berkarir, meliputi (a) fleksibilitas dan adaptabilitas/flexibility and adaptability, 
seorang pendidik mampu mengadaptasi perubahan dan fleksibel dalam belajar dan berkegiatan dalam kelompok. (b) inisiatif dan mengatur diri sendiri/ initiative and self direction, pendidik mampu mengelola tujuan dan waktu, bekerja secara independen dan menjadi pendidik yang mampu mengatur diri sendiri. (c) interaksi sosial dan budaya/sosial and cross cultural interaction, pendidik mampu berinteraksi dan bekerja secara efektif dengan kelompok yang beragam. (d) produktivitas dan akuntabilitas/productivity and accountability, pendidik mampu mengelola proyek dan menghasilkan produk. dan (e) kepemimpinan dan tanggungjawab/leadership and responsibility. pendidik mampu memimpin teman-temannya dan bertanggung jawab kepada masyarakat luas. (2) learning and innovation skills adalah keterampilan belajar dan berinovasi meliputi (a) berpikir kritis dan mengatasi masalah/critical thinking and problem solving, pendidik dapat menggunakan cara berpikir sistem, membuat keputusan dan mnegatasi masalah. (b) komunikasi dan kolaborasi/communication and collaboration, pendidik mampu berkomunikasi dengan jelas dan melakukan kolaborasi dengan anggota kelompok lainnya. (c) kreatif dan inovasi/creativity and innovation. Pendidik mampu berpikir kreatif, bekerja secara kreatif dan menciptakan inovasi baru. (3) information media and technology skills adalah keterampilan teknologi dan media informasi meliputi (a) literasi information/information and communication literacy, pendidik mampu mengakses informasi secara efektif dan efisien, mengevaluasi informasi yang akan digunakan secara kritis dan kompeten. (b) literasi media/media litercy pendidik mampu memilih dan mengembangkan media yang digunakan untuk berkomunikasi dan (c) literasi ICT/Information and communication technology literacy. Pendidik mampu menganalisis media informasi dan menciptakan media yang sesuai untuk melalukan komunikasi (Etiska Ayu Wijaya, Dwi Agus Sudjimat dan Amat Nyoto, 2016: 268).

\section{A. Problematika Kepemimpinan Pendidikan Dasar dan Pengembangan Mutu SDM MI di Abad 21}

Sejak awal tahun 1970-an sistem pendidikan Indonesia mengalami perubahan secara terus menerus, sejalan dengan program pembangunan di bidang pendidikan yang dimulai dilaksanakan secara terprogram sejak 40 tahun yang lalu. Sejak saat itu pemerintah mulai merintis program pemerataan dan perluasan kesempatan belajar bagi semua warga negara Indonesia, pada semua jenis dan jenjang pendidikan, khususnya kesempatan memperoleh pendidikan dasar. Disamping untuk perluasan kesempatan belajar, pembangunan pendidikan diarahkan juga pada peningkatan mutu, relevansi dan efesien pada semua jenis dan jenjang pendidikan (Ace Suryadi, 2014:54).

Beberapa isu-isu kebijakan yang belum berhasil tertangani sejak tahun 1970-an umumnya terkait mengenai masalah dalam pemerataan, keadilan, mutu pendidikan dan relevansi pendidikan pada setiap jenjang pendidikan hingga sekarang. Inilah diantara isu-isu atau permasalahan tersebut.

1. Membangun pendidikan karakter bangsa.

Sampai saat ini pelaksanaan pembangunan nasional cenderung lebih tertuju dan berorientasi terhadap tujuan yang lebih pragmatis, yaitu memuaskan kebutuhan material jangka pendek dan hanya berfokus akan hal itu. Permasalahan tersebut muncul dan bermula dari pembangunan pendidikan nasional yang lebih menonjolkan aspek material (pembangunan) ketimbang aspek kemanusiaan. Program-program pembangunan pendidikan nasional lebih memprioritaskan pengadaan sarana dan prasarana fisik dari sebuah lembaga pendidikan, daripada pengembangan kapasitas manusia yang berkualitas, baik sebagai pemikir, perencana, pengelola, pelaksana, maupun peneliti, pengembang, dan analisis kebijakan dalam pengelolaan pendidikan nasional. Sampai saat ini pendidikan nasional masih mengalami kesulitan dalam menghasilkan lulusan yang berkualitas, bermutu, cakap, dan 
kreatif yang dapat berfungsi sebagai sumber penggerak dalam berbagai bidang pembangunan nasional (Ace Suryadi, 2014:94).

2. Pendidikan dasar untuk semua

Pemerintah bertugas memberikan pelayanan pendidikan dasar yang bermutu, merata, berkeadilan dan relevan dengan kebutuhan semua warga negara tanpa kecuali, negara mengusahakan pemerataaan pendidikan. Dalam Education for All (APPEAL UNESCO) pendidikan dasar adalah program permulaan yang substansinya dikemas secara integral dalam berbagai program, yaitu pendidikan kemampuan dasar untuk belajar, pendidikan karakter bangsa, pendidikan substansi belajar dasar dan pendidikan kecakapan hidup yang beorientasi terhadap kebutuhan lingkungan. Sampai sekarang pemerintah belum memiliki kebijakan pendidikan dasar yang jelas dan terukur berkaitan dengan visi misinya, pengelolaannya dalam muatan dan proses pembelajarannya, serta sistem evaluasi yang mampu mengukur capaian tujuan seperti yang dituangkan dalam UU Sisdiknas (sistem pendidikan nasional). (Ace Suryadi, 2014:107-108)

Mutu pendidikan memang telah diukur selama ini menggunakan capaian skor UASBN-SD atau UN SMP sebagai salah satu indikator keberhasilan kinerja (IKK). Masalahnya adalah mutu pendidikan dasar yang diukur umumnya hanya pengetahuan yang diperoleh peserta didik pada setiap mata pelajaran yang diujikan. Keberhasilan mencapai IKK itu sesungguhnya semu karena jika ukurannya hanya skor UASBN atau UN maka tujuan kecakapan dasar, pembentukan karakter dan kemampuan untuk belajar sepanjang hayat tidak dengan sendirinya dapat tercapai oleh peserta didik.

3. Desentralisasi dan Otonomi Pendidikan

Pelaksanaan otonomi dan desentralisasi pendidikan telah membawa arah dan harapan baru bagi terciptanya manajemen pelayanan pendidikan yang semakin baik, berkualitas, bermutu dan berorientasi terhadap kebutuhan masyarakat dan pembangunan. Namun, sebuah kebijakan desentralisasi dan otonomi pendidikan tampaknya tidak serta merta akan membawa kondisi yang lebih baik jika tidak diimplementasikan secara cermat dan merata pengalaman diberbagai negara yang telah lebih dulu melaksanakan otonomi pendidikan menunjukkan hasil yang bervariasi. Banyak kendala yang mengakibatkan desentralisasi pendidikan yang telah dilakukan tersebut tidak menghasilkan perubahan yang positif dalam kinerja sistem pendidikan yang bersangkutan. Hal ini merupakan tantangan besar setelah diberlakukannya kebijakan dari desentralisasi otonomi pendidikan. Dalam program wajib belajar pendidikan dasar 9 tahun yang telah diberlakukan. Permasalahan paling besar dalam pelaksanaan desentralisasi pendidikan adalah ketergantungan daerah yang semakin besar pula terhadap pemerintah baik dalam penyusunan program maupun dalam pendanaan pembangunan pendidikan daerah tersebut, daerah masih belum bisa sepenuhnya mandiri (Ace Suryadi, 2014:107-108).

\section{B. Pemikiran Solutif Mengatasi Problematika Kepemimpinan Pendidikan Dasar dan Pengembangan Mutu SDM MI Abad 21}

1. Perspektif dalam pendidikan karakter

Solusi terhadap permasalahan karakter bangsa akan terwujud ketika pendidikan itu bermutu tinggi sehingga menghilangkan problem yang telah ada. Pendidikan yang bermutu dan berkualitas menawarkan program dan strategi yang memiliki dampak jangka panjang bagi tumbuhnya karakter seseorang maupun kolektif. Pendidikan yang bermutu sebagai upaya preventif untuk mencegah degradasi moral dan karakter seseorang atau masyarakat secara berkelanjutan. Terbentuknya karakter dan budaya bangsa hanya dapat diwujudkan jika program dan proses pendidikan itu tidak terlepas dari faktor lingkungan yang sarat dengan nilai sosial, budaya dan kemanusiaan, dalam pembentukan karakter banyak yang memiliki andil untuk dapat mewujudkan hal tersebut. 
Nilai tidak dapat hanya diajarkan dan di dapatkan secara instan tetapi harus dilakukan dengan bentuk pembiasaan, pemahaman, keteladanaan, dan aplikasi secara terus-menerus hingga akhirnya ditemukan makna dari suatu nilai karakter (Ace Suryadi, 2014:95-96). Dengan kata lain hanya pada institusi pendidikan yang berkarakterlah, peserta didik akan tumbuh dan berkembang sebagai manusia yang berkarakter dan bermutu. Sekolah yang berkarakter memiliki beberapa ciri baik dilihat dari organisasi siswanya, pemimpinnya, iklim sekolahnya serta manajemen pendidikannya di sekolah yang mampu membentuk perilaku warganya untuk berperilaku sesuai dengan norma dan standar yang di anut.

2. Pendidikan Dasar untuk Semua

Pendidikan dasar bertujuan untuk membentuk karakter, serta kemampuan dan kecakapan dasar yang berguna bagi semua warga negara, karakter tidak dibentuk secara cepat namun perlu proses oleh sebab itu karakter harus ditanamkan dalam diri peserta didik sejak dini. Layanan pendidikan dasar dilakukan atas dasar prinsip keadilan tanpa membedakan suku bangsa, golongan, jenis kelamin, tempat tinggal dan latar belakang sosial ekonomi, pendidikan untuk semua tak melihat keberagaman yang ada "multikultural". Keadilan dalam layanan pendidikan hanya dapat diwujudkan melalui kebijakan pendidikan dasar yang bebas biaya. Jika pemerintah belum memberlakukan pendidikan dasar bebas biaya maka anak-anak miskin kurang berpeluang untuk memperoleh layanan pendidikan yang bermutu dan berkualitas.

Pemerintah bertugas memberikan pelayanan pendidikan dasar yang bermutu, berkualitas, merata, berkeadilan, relevan dengan kebutuhan lulusan untuk hidup sebagai warga negara dan masyakarat. Keberhasilan dalam pembangunan pendidikan dasar bukanlah di ukur dengan banyaknya gedung sekolah, luasnya bangunan, banyaknya pendidik dan sarana belajar di sekolah serta banyaknya pengetahuan peserta didik tetapi dilihat dari dampak pendidikan terhadap pembentukan warga negara yang baik dan bertanggung jawab. Lebih operasional dari itu adalah pembentukan dari karakter dan penguatan kemampuan dasar untuk belajar yang berguna bagi lulusan untuk melaksanakan hak dan kewajiban sebagai warga negara yang baik dan bertanggung jawab (Ace Suryadi, 2014:139).

3. Penguatan Desentralisasi dan Otonomi Pendidikan

Kebijakan desentralisasi dan otonomi pendidikan tidak dapat mengurangi bahkan dapat melahirkan, ketergantungan pemerintah provinsi dan kabupaten/kota terhadap pemerintah pusat. Saling ketergantungan itu bukan hanya dalam pendanaan, tetapi juga dalam pengembangan kebijakan dan program (pembangunan) pendidikan yang berlaku disetiap daerah. Untuk mewujudkan pelayanan yang adil dan merata bagi semua "anak bangsa", maka pembagian urusan pendidikan antar tingkat pemerintahan harus jelas, dan terukur juga tertulis, kebijakan dan program mana yang dibiayai oleh pemerintah, mana yang dibiayai oleh provinsi, mana yang dibiayai oleh kabupaten/kota dan mana yang di bebankan kepada masyarakat.

Sebuah langkah alternatif dalam pembagian tugas dan tanggungjawab antar tingkat pemerintahan sebagai berikut:

Pertama, pemerintah daerah kabupaten/kota seyogianya bertangggung jawab kepada tingkatan yang paling operasional dalam pengelolaan dan penyelenggaraan pendidikan yaitu pada tingkat satuan pendidikan, untuk mengelola dan menangani urusan yang berkaitan dengan operasi satuan pendidikan yang terfokus pada kabupatennya. Kedua, pemerintah provinsi dapat bertanggungjawab dalam membangun infrastruktur pendidikan yang berstandar nasional, seperti bangunan sekolah (material). Ketiga, urusan pemerintah pusat bertanggung jawab langsung terhadap maju mundurnya sistem pendidikan nasional, terutama yang berkaitan dengan mutu pendidikan dan daya saing bangsa di era globalisasi abad 21 (Ace Suryadi, 2014:155-156). 
Dalam upaya mencapai pendidikan dasar yang bermutu untuk semua, pemerintah harus melakukan langkah-langkah strategis, seperti penyediaan beasiswa bagi peserta didik miskin sebagai langkah awal dalam mewujudkan pendidikan dasar bebas biaya (kebijakan wajib belajar 9 tahun); pembangunan unit sekolah/madrasah baru minimal 1 lembaga di setiap kecamatan terutama pada satuan SMP atau sederajat; penyediaan dan pemenuhan kebutuhan pendidik yang bermutu untuk sekolah/madrasah baru antara lain melalui upaya peningkatan mutu lembaga pendidikan tinggi kependidikan (LPTK); pengembangan pendidikan dasar 9 tahun satu atap pada tingkat kabupaten/kota; dan peningkatan partisipasi masyarakat terhadap akses pendidikan menengah dalam rangka mencapai target perwujudan pendidikan menengah universal (Tim PGRI, 2014:103).

\section{PENUTUP}

Kepemimpinan kepala sekolah yang dapat memberikan progress terhadap sekolah harus dapat meningkatkan kreativitas sekaligus dapat mendorong terhadap peningkatan kompetensi guru. Abad 21 adalah abad yang meminta kualitas dan mutu dalam segala usaha dan hasil kerja manusia, dengan sendirinya abad 21 meminta sumber daya manusia yang berkualitas, yang dihasilkan oleh lembaga-lembaga yang dikelola secara profesional sehingga membuahkan hasil unggulan. Pengembangan SDM meliputi 1) pelatihan, 2) pengembangan, 3) pengembangan karir, 4) penilaian kinerja.

Problematika kepemimpinan pendidikan dasar yaitu terkait dengan masalah dalam pemerataan, keadilan, mutu dan relevansi pendidikan pada setiap jenjang pendidikan. Beberapa problem yang dibahas yaitu mengenai 1) Membangun pendidikan karakter bangsa, yang dimulai dengan bentuk pembiasaan, pemahaman, keteladanaan dan berjalan secara terus menerus hingga akhirnya diperoleh karakter dari sebuah nilai, 2) Pendidikan dasar untuk semua haruslah berlandaskan dengan pendidikan multikultural dan Education for All yang menjamin bahwa seluruh anak bangsa berhak mendapatkan pendidikan, 3) Desentralisasi dan Otonomi Pendidikan harus jelas pembagian urusan pendidikan antar tingkat pemerintahan dan terukur juga tertulis berbagai kebijakan atau program yang dibiayai oleh pemerintah, provinsi atau kabupaten.

\section{DAFTAR PUSTAKA}

Andang. (2014). Manajemen dan Kepemimpinan Kepala Sekolah. Yogyakarta:Ar-ruzz Media. Appeal (1991) Education for All in the Asia-Pacific Region. Dokumen kelompok kerja APPEAL UNESCO Asia-Pasific Bangkok.

Ayu Wijaya, Etiska. Dwi Agus Sudjimat dan Amat Nyoto (2016). Transformasi pendidikan Abad 21 Sebagai Tuntutan Pengembangan Sumber Daya Manusia di Era Global. Universitas Negeri Malang. Volume 1 Tahun 2016- ISSN 2528-259X.

Bafadal, Ibrahim. (2004) Peningkatan Profesionalisme Guru MI dalam Rangka Manajemen Mutu Berbasis Madrasah. Jakarta: Bumi aksara.

Depdiknas. (2006). Rencana Strategis Pendidikan Nasional Periode 2005-2009. Jakarta: Sekretariat Jenderal Depdiknas.

Deti, Mulyati. (2012). Manjarmen Pengembanagn Sumber Daya Aparatur Eselon III dalam rangka peningkatan Kinerja Individu. Disertasi. Bandung: Universitas Pendidikan Indonesia.

Kurniadin, Didin \& Imam Machali. (2014). Manajemen Pendidikan Konsep dan Prinsip Pengelolaan Pendidikan. Jogjakarta: Ar-ruzz Media.

Permendiknas No. 19 tahun 2007.

Suryadi, Ace. (2014). Pendidikan Indonesia Menuju 2025. Bandung: PT Remaja Rosdakarya. Tim PGRI. (2014). Pendidikan Untuk Transformasi Bangsa. Jakarta: PT Kompas Media Nusantara. 